\title{
Western Marsh Harriers Circus aeruginosus from nearby breeding areas migrate along comparable loops, but on contrasting schedules in the West African-Eurasian flyway
}

\author{
Wouter M. G. Vansteelant ${ }^{1,2}\left([) \cdot\right.$ Raymond Klaassen $^{1,3,4} \cdot$ Roine Strandberg $^{3} \cdot$ Kjell Janssens $^{5} \cdot$ Filiep T'Jollyn $^{5}$. \\ Willem Bouten ${ }^{2} \cdot$ Ben J. Koks ${ }^{1} \cdot$ Anny Anselin ${ }^{5}$
}

Received: 7 January 2020 / Revised: 27 April 2020 / Accepted: 5 May 2020 / Published online: 16 May 2020

(c) The Author(s) 2020

\begin{abstract}
Much of our knowledge about migratory behaviour comes from single-population tracking studies. Some such studies had a considerable impact on migration research at large. However, it is often unclear how representative such studies are for other populations, even of the same species. We compared migration corridors and schedules of GPS-tracked adult Western Marsh Harriers (Circus aeruginosus) from two nearby breeding areas within the West African-Eurasian flyway: the Low Countries (LC, $N=6$ ) and southern Sweden (SW, $N=4)$. Assuming the migration patterns revealed by decade-old satellite-tracking of SW harriers are representative for the species, we expected LC harriers to make a narrow loop migration involving a western spring detour out of Africa, but according to an earlier schedule tuned to the earlier onset of spring in the Low Countries. In autumn, LC harriers migrated significantly further west than SW harriers all the way to their common non-breeding range. In spring, both groups detoured westward across the Sahara, as expected, and diverged towards their breeding areas after reaching mainland Europe. LC harriers migrated slightly earlier than SW harriers in autumn. However, LC harriers unexpectedly left their non-breeding sites up to a month before SW harriers, after which they made long stop-overs in northwest Africa. Late-departing SW harriers forewent these stop-overs, and thus caught up with LC harriers in northwest Africa, so that both groups reached their breeding areas simultaneously. While we anticipated strong overlap between LC and SW migration corridors in spring, we failed to anticipate the earlier and more variable spring departures of LC harriers. Early spring departures did not result in earlier arrivals by LC harriers. Instead, we suspect they departed early to escape faster deteriorating foraging conditions at their non-breeding sites. Such environmental modulation of migratory behaviour may complicate generalization of migration patterns in other birds.
\end{abstract}

Keywords Flexibility $\cdot$ GPS-tracking $\cdot$ Phenology $\cdot$ Raptors $\cdot$ Route choice $\cdot$ Weather

Communicated by N. Chernetsov.

Electronic supplementary material The online version of this article (https://doi.org/10.1007/s10336-020-01785-6) contains supplementary material, which is available to authorized users.

Wouter M. G. Vansteelant

w.m.g.vansteelant@uva.nl

1 Dutch Montagu's Harrier Foundation, Scheemda, The Netherlands

2 Institute for Biodiversity and Ecosystem Dynamics, University of Amsterdam, Amsterdam, The Netherlands

3 Lund University, Lund, Sweden

4 Groningen University, Groningen, The Netherlands

5 Research Institute for Nature and Forest, Brussels, Belgium 


\section{Zusammenfassung}

Rohrweihen Circus aeruginosus nahegelegener Brutgebiete ziehen in vergleichbaren Schleifen jedoch mit voneinander abweichenden Zeitverläufen entlang des westafrikanisch-eurasischen Zugweges.

Ein Großteil unserer Erkenntnisse über das Zugverhalten stammt aus Tracking-Studien einzelner Populationen. Einige dieser Studien hatten eine erhebliche Auswirkung auf die Zugforschung insgesamt. Es ist jedoch oft unklar, wie repräsentativ solche Studien für andere Populationen, selbst der gleichen Art, sind. Wir verglichen die Zugkorridore und den zeitlichen Verlauf entlang des westafrikanisch-eurasischen Zugweges von mittels GPS verfolgten adulten Rohrweihen (Circus aeruginosus) aus zwei nahegelegenen Brutgebieten: den Beneluxländern (engl. Low Countries, LC; $N=6$ ) und Südschweden (SW, $N=4$ ). Unter der Annahme, dass das durch die jahrzehntelangen Satellitenverfolgungen entdeckte Zugmuster von SW-Rohrweihen für die Art repräsentativ ist, erwarteten wir, dass LC-Rohrweihen einen engen Schleifenzug machen. Dieser sollte auf dem Frühjahrszug einen westlichen Umweg aus Afrika einschließen. Jedoch wäre dann als Anpassung an den früheren Frühjahrsbeginn in den Beneluxländern ein früherer zeitlicher Verlauf zu erwarten. Im Herbst zogen LC-Rohrweihen deutlich weiter westlich als SW-Rohrweihen bis in ihr gemeinsames Überwinterungsgebiet. Im Frühjahr flogen beide Gruppen erwartungsgemäß westwärts über die Sahara und zogen nach dem Erreichen des europäischen Festlandes auseinander in Richtung ihrer Brutgebiete. LC-Rohrweihen flogen im Herbst etwas früher los als SW-Rohrweihen. Allerdings verließen LC-Rohrweihen die Überwinterungsgebiete unerwartet bis zu einem Monat vor den SW-Rohrweihen, wonach sie lange Zwischenstopps in Nordwestafrika einlegten. Später abziehende SW-Rohrweihen verzichteten auf diese Zwischenstopps und holten somit die LC-Rohrweihen in Nordwestafrika ein, sodass beide Gruppen gleichzeitig ihre Brutgebiete erreichten. Wir erwarteten zwar eine starke Überschneidung zwischen LC- und SW-Zugkorridoren im Frühjahr, rechneten jedoch nicht mit den früheren und variableren Frühjahrsabzügen der LC-Rohrweihen. Frühere Frühjahrsabzüge führten nicht zu einem früheren Eintreffen der LC-Rohrweihen. Stattdessen vermuten wir, dass sie früh abzogen, um die sich schneller verschlechternden Futterbedingungen in ihren Überwinterungsgebieten zu entgehen. Ein solches an die Umwelt angepasstes Zugverhalten könnte die Verallgemeinerung von Zugmustern bei anderen Vogelarten erschweren.

\section{Introduction}

Over the past two decades tracking technology has allowed us to map and describe long-distance migration strategies for numerous migrant landbirds. A recent meta-analysis of tracking studies revealed that African-Palearctic migrants commonly show weak connectivity between breeding and non-breeding areas (Finch et al. 2017). Such weak connectivity likely arises in species where juveniles that were born in the same population, or even the same nest, are pushed into different parts of the non-breeding range by stochastic winds on their first migration (Finch et al. 2017; Vansteelant et al. 2017a). However, patterns of migratory connectivity are often much more complex, involving population-specific migration routes or non-breeding areas (Ouwehand et al. 2016; Jiguet et al. 2019). We still struggle to explain this variation due to a lack of data and knowledge about the development of individual migration patterns. Moreover, the interannual consistency of individual non-breeding sites, route choice and migration schedules all differ substantially between species and even populations (Vardanis et al. 2011, 2016; Both et al. 2016; Hasselquist et al. 2017; van Wijk et al. 2017). This further complicates the challenge to generalize migration patterns from single-population studies, especially while few studies have compared migration corridors and schedules across multiple populations of any one species (e.g. Trierweiler et al. 2014, Ouwehand et al. 2016; Briedis et al. 2016).
Here, we compare migration corridors and schedules of adult Western Marsh Harriers Circus aeruginosus (hereinafter: Marsh Harrier) breeding in Flanders (Belgium) and the Netherlands, together known as the Low Countries (LC), with the previously well-studied migration patterns of their conspecifics breeding in southern Sweden (SW). Although a large portion of juvenile Marsh Harriers and some adult females stay in Europe during the northern winter, most adults from the northern populations migrate long distances to sub-Saharan Africa (Strandberg et al. 2008; Bijlsma 2009, Panuccio et al. 2013). Ring recoveries indicate that harriers from both our study populations use the West African-European flyway and have overlapping non-breeding ranges in West Africa (Fransson and Pettersson 2001; BeBirds 2019, Vogeltrektatlas 2019). The fact that $\sim 50 \%$ of ring recoveries in West Africa come from large floodplains and coastal wetlands (Bijlsma 2009) indicates that Marsh Harriers concentrate in or near wetlands, which may exacerbate the mixing of LC and SW harriers in the non-breeding range. Assuming such a common flyway and non-breeding range, we expect to find only minor differences in the route choice and timing of LC and SW harriers. And ideally, we should be able to predict those differences using conventional hypotheses about optimal migration behaviour.

At the species level Marsh Harriers exhibit a broad-front migration pattern, as they do not circumvent barriers like large water bodies via geographical bottlenecks as much as obligate soaring migrants do (Leshem and Yom-Tov 
1996; Spaar and Bruderer 1997; Meyer et al. 2000; Agostini and Panuccio 2010). However, in the western flyway, satellite-tracked SW harriers showed a more concentrated passage through the Strait of Gibraltar in spring (Klaassen et al. 2010), even though visual observations did not show a greater spring than autumn passage at this site (De la Cruz et al. 2011a, b). This greater spring aggregation of SW harriers seems to result at least in part from the fact that Marsh Harriers engage in a western detour across the Sahara (Klaassen et al. 2010), as found in other raptors using the West African-Eurasian flyway (Vidal-Mateo et al. 2016; Vansteelant et al. 2017b). This common detour seems to be shaped predominantly by the prevalence of north-easterly winds that increase the cost and riskiness of more direct desert-crossings in spring (Strandberg et al. 2010; Klaassen et al. 2011, 2014; Vansteelant et al. 2017b). For harriers, milder climatic conditions near the Atlantic Ocean may also provide better foraging opportunities than the interior of the Sahara, though it is unclear to what extent this motivates the route choice of SW harriers that rarely stop-over in spring (Klaassen et al. 2008, 2010; Strandberg et al. 2008). Individual route choice of SW harriers is also highly flexible within their seasonal migration corridors, depending on annual wind conditions (Klaassen et al. 2011; Vardanis et al. 2011, 2016). Like other thermal-soaring migrants, Marsh Harriers thereby exhibit a high tolerance for wind drift, for which they tend to compensate only when approaching their seasonal destinations, or critical bottlenecks along the way (Alerstam 2001; Klaassen et al. 2011; Vansteelant et al. 2017b). Assuming the behaviour of SW harriers is representative for other long-distance migrant individuals and populations in the West African-Eurasian flyway, we expect LC harriers to engage in an even narrower loop migration than SW harriers. More specifically, we expect LC harriers to use a more western migration corridor than SW harriers in autumn, but showing increasing overlap with the SW migration corridor due to stochastic wind drift, and due to convergence of LC and SW harriers into common non-breeding areas. In spring, we expect all harriers to drift out of West Africa via the western detour, and to diverge towards their respective breeding areas only after crossing the Strait of Gibraltar.

The main factor determining the temporal organization of bird migration cycles seems to be the timing of seasonal fluxes in food availability along their flyways (Somveille et al. 2015; Thorup et al. 2017). Given the earlier onset of spring at lower latitudes, we expect LC harriers to migrate and breed at most a few weeks before SW harriers (Conklin et al. 2010; Briedis et al. 2016). To ensure such a timely arrival, we expect that LC harriers will also depart from West Africa 1-2 weeks before SW harriers (Nilsson et al. 2013; Both et al. 2016). Indeed, LC harriers are unlikely to achieve an earlier arrival by reducing stop-over time with respect to SW harriers, given that SW harriers rarely engage in stop-overs (Strandberg et al. 2008; Klaassen et al. 2010; Vardanis et al. 2011, 2016). It is also unlikely they would travel at higher air speed than SW harriers, given that wind support and thermal climb rates are the main determinants of thermal-soaring performance (Mellone et al. 2012; Vansteelant et al. 2015, 2017c). Finally, we expect the early spring migration and breeding of LC harriers to carry-over to a similarly advanced autumn migration schedule (cf. Conklin et al. 2010, Briedis et al. 2016). Autumn departure timing is thereby likely to be more individually flexible than spring departure timing, depending on breeding success (Vardanis et al. 2011, 2016). But on average, we expect LC harriers to start their seasonal migrations 1-2 weeks before SW harriers, and to travel at comparable speed by only stopping-over under adverse wind conditions (Thorup et al. 2006).

\section{Methods}

\section{Catching and tracking}

Marsh Harriers were caught using a bal-chatri on the nest (Sweden) or a noose-trap on a sitting-pole in the vicinity of the nest (Belgium, Netherlands). Tags were fitted with the body-loop attachment method using a Teflon-tube harness. Since 2012 and 2013, respectively, four and seven adult Marsh Harriers have been caught and tagged with UvABiTS GPS-trackers (Bouten et al. 2013) in the Netherlands and Flanders (Belgium), collectively known as the Low Countries (LC). In Sweden, 14 Marsh Harriers were tracked by satellite telemetry already a decade ago (Strandberg et al. 2008; Klaassen et al. 2010). However, to explicitly compare migration patterns between our two study populations, we used tracking data of 5 adult SW harriers that were equipped with satellite-based GPS-trackers since 2011 (Solar Argos/ GPS PTTs, Microwave Telemetry), offering a comparable resolution and precision of tracking data compared to $\mathrm{LC}$ harriers.

\section{Interpreting long-distance migrations}

The adult LC and SW harriers for which migration data were obtained (respectively, 4 of 7 in BE, two of four in NL, 4 of 5 in SW) mostly used the West African-Eurasian flyway in both seasons (Table 1). The notable exception was a bird from Flanders (BE_M4) that returned via Italy and perished in the Alps (excluded in our analyses of successfully completed journeys).

We determined the start and end dates of each migratory journey by interpretation of tracks in Google Earth. Although Marsh Harriers may engage in so-called premigratory movements to stop-over sites near the breeding 
Table 1 Summary of timing and stop-over duration by each Marsh Harrier during autumn and spring migration, respectively

\begin{tabular}{|c|c|c|c|c|c|c|c|c|c|c|c|}
\hline \multirow[t]{2}{*}{ Season } & \multirow[t]{2}{*}{ Pop } & \multirow[t]{2}{*}{ ID } & \multirow[t]{2}{*}{ Nr. trips } & \multicolumn{2}{|c|}{$\begin{array}{l}\text { Julian departure } \\
\text { date }\end{array}$} & \multicolumn{2}{|c|}{$\begin{array}{l}\text { Julian arrival } \\
\text { date }\end{array}$} & \multicolumn{2}{|c|}{$\begin{array}{l}\text { Nr. stop-over } \\
\text { days }\end{array}$} & \multicolumn{2}{|c|}{$\begin{array}{l}\text { Total dura- } \\
\text { tion }\end{array}$} \\
\hline & & & & Mean & SD & Mean & SD & Mean & SD & Mean & SD \\
\hline \multirow[t]{10}{*}{ Autumn } & \multirow[t]{6}{*}{ LC } & BE_M1 & 1 & 07 Sep & - & $06 \mathrm{Oct}$ & - & 5 & - & 30 & - \\
\hline & & BE_M2 & 4 & 02 Sep & 16 & $28 \mathrm{Sep}$ & 12 & 1 & 1 & 28 & 10 \\
\hline & & BE_M3 & 1 & 04 Sep & - & 04 Oct & - & 7 & - & 31 & - \\
\hline & & BE_M4 & 1 & $29 \mathrm{Aug}$ & - & $01 \mathrm{Oct}$ & - & 0 & - & 34 & - \\
\hline & & NL_M1 & 3 & $01 \mathrm{Sep}$ & 6 & $30 \mathrm{Sep}$ & 4 & 5 & 3 & 30 & 4 \\
\hline & & NL_M2 & 4 & 28 Aug & 7 & $22 \mathrm{Sep}$ & 9 & 2 & 3 & 27 & 6 \\
\hline & \multirow[t]{4}{*}{ SW } & SW_F1 & 5 & 19 Sep & 6 & $14 \mathrm{Oct}$ & 10 & 5 & 2 & 27 & 7 \\
\hline & & SW_F3 & 1 & $12 \mathrm{Sep}$ & - & 18 Oct & - & 7 & - & 37 & - \\
\hline & & SW_M1 & 1 & $07 \mathrm{Sep}$ & - & 24 Oct & - & 12 & - & 48 & - \\
\hline & & SW_M2 & 1 & 09 Sep & - & $01 \mathrm{Oct}$ & - & 2 & - & 23 & - \\
\hline \multirow[t]{10}{*}{ Spring } & \multirow[t]{6}{*}{ LC } & BE_M1 & 1 & $27 \mathrm{Feb}$ & - & 29 Mar & - & 7 & - & 31 & - \\
\hline & & BE_M2 & 4 & 05 Mar & 4 & $10 \mathrm{Apr}$ & 3 & 13 & 3 & 37 & 6 \\
\hline & & BE_M3 & 1 & $21 \mathrm{Feb}$ & - & $04 \mathrm{Apr}$ & - & 17 & - & 43 & - \\
\hline & & BE_M4 & 0 & 08 Mar & - & - & - & - & - & - & - \\
\hline & & NL_M1 & 3 & $22 \mathrm{Feb}$ & 9 & $06 \mathrm{Apr}$ & 9 & 15 & 2 & 45 & 4 \\
\hline & & NL_M2 & 4 & $21 \mathrm{Feb}$ & 10 & $08 \mathrm{Apr}$ & 2 & 18 & 7 & 47 & 10 \\
\hline & \multirow[t]{4}{*}{ SW } & SW_F1 & 5 & 16 Mar & 3 & $12 \mathrm{Apr}$ & 5 & 4 & 2 & 27 & 4 \\
\hline & & SW_F3 & 1 & $05 \mathrm{Apr}$ & - & 27 Apr & - & 2 & - & 23 & - \\
\hline & & SW_M1 & 1 & 17 Mar & - & $14 \mathrm{Apr}$ & - & 6 & - & 29 & - \\
\hline & & SW_M2 & 0 & - & - & - & - & - & - & - & - \\
\hline
\end{tabular}

Bird IDs are composed of an abbreviation of the country where birds were tagged ( $B E$ Belgium, $N L$ the Netherlands, $S W$ Sweden), their sex ( $M$ male, $F$ female) and an individual number. We consider birds breeding in the Low Countries $(\mathrm{LC}=\mathrm{BE}+\mathrm{NL})$ as a distinct population in our analyses. BE_M4 died during return migration, so total duration and stop-over duration could not be calculated. SW_M2 died at wintering grounds, so no statistics could be computed for return migration area (Strandberg et al. 2008), we considered that migration started as soon as a bird left its breeding area in autumn or its last non-breeding site in spring. That is because premigratory movements sensu Strandberg et al. (2008) typically occur well before the main migration period, and none of our birds engaged in such early movements. We analogously defined arrival dates as the days on which the Marsh Harriers reached their first non-breeding site in autumn or their breeding area in spring. We distinguished non-breeding sites from stop-over sites as sites south of the Sahara that harriers used for at least 2-3 weeks. This classification is supported by the fact that individuals for which we tracked several migrations consistently returned to the non-breeding sites we identified in this manner, while not using any other site so consistently (Table S2).

\section{Data processing}

After partitioning the annual cycle in breeding, migration and non-breeding periods, we resampled all data to hourly intervals, starting from the first fix in each time series and tolerating a deviance of $10 \mathrm{~min}$ between a realized fix and a perfect hourly interval. Most of the obvious incorrect fixes could be discarded by iteratively $(3 \mathrm{x})$ removing fixes with a forward trajectory speed $>30 \mathrm{~ms}^{-1}$. In addition, we found $\sim 10$ faulty fixes that resulted in an erroneous classification of stop-overs. These were flagged and removed manually in our R scripts to ensure reproducibility of our work (see section "Data availability").

We calculated daily travel distances as the loxodrome distance between the first and the last fix obtained on each day, assuming these fixes were recorded at roost sites. Using a threshold of $25 \mathrm{~km} \mathrm{day}^{-1}$, we distinguished between travel days and stop-over days (cf. Strandberg et al. 2008; Klaassen et al. 2011). We then segmented each trip into travel vs. stop-over segments and calculated the duration of each stopover event (in days) by summing the time intervals between the relevant GPS-fixes. We then summed the total number of stop-over days per trip and calculated the total duration of each journey by subtracting the Julian start date from the Julian end date of each trip.

\section{Annotating wind data}

In order to determine whether wind selectivity influenced stop-over decisions we calculate daily mean tailwind strength 
according to the procedure used by Klaassen et al. (2010). We selected the fixes closest to 6AM, 12AM and 6PM on each day, and used the RNCEP package to interpolate $\mathrm{u}$ - and $\mathrm{v}$-wind components from the NOAA NCEP global atmospheric reanalysis model (Kemp et al. 2012). We interpolated wind components from the $925 \mathrm{mb}$ pressure level, equivalent to a flight height of approx. $750 \mathrm{~m}$ asl, which is commonly used in studies of (facultative) soaring migrants (Klaassen et al. 2011; Vansteelant et al. 2015). We then averaged these wind components per day, giving two times the weight to wind conditions at noon, thus accounting for the diurnal activity pattern of Marsh Harriers. From these mean components we derived daily wind speed and direction, and then calculated the daily tailwind strength relative to the bird's intended travel direction (Chapman et al. 2011; Vansteelant et al. 2017b). The intended travel direction was approximated as the mean daily track direction of LC and SW harriers per continent and per season.

\section{Statistical analyses}

We used mixed linear models to assess differences in migration corridors and timing between groups and to assess how departure and stop-over schedules affected seasonal migratory performance (i.e. arrival timing) between the two populations. We thereby accounted for repeated sampling of the same individuals by randomly varying individual intercepts in the lmer() function from the lme4 package (Bates et al. 2015). Inspection of residual plots revealed a normal error distribution was most appropriate for all our models. To estimate effect sizes and the significance of differences between groups from the mixed effect models we used the emmeans() function from the emmeans package, using the Kenward-Rogers method for estimating degrees of freedom in each model.

To gauge wind selectivity, we compared daily tailwind strength on travel vs. stop-over dates. We tested this separately between continents and regions, given that these regions are dominated by different wind regimes, and again accounting for non-random sampling of repeated journeys using a mixed model structure (Klaassen et al. 2008, 2011; Vansteelant et al. 2017b).

All data processing, visualization and modelling were conducted in $R$ v.3.3.3 (R Core Development Team 2017). Maps and graphs were produced using the ggplot2 package (Wickham 2009). All our codes are made available through GitHub (see "Data availability") along with a script to instal and read all the packages needed to reproduce our analyses.

\section{Results}

Our focus is on comparing seasonal migration corridors and timing of Marsh Harriers breeding in the Low Countries (LC, $N=6$ ) and Sweden (SW, $N=4$ ) (Fig. 1). Variability and flexibility in seasonal routes and schedules are detailed in Table 1 and Supplementary Information Fig. S1.

\section{Autumn migration corridors and non-breeding sites}

Autumn migration corridors of LC and SW harriers slightly overlapped in NW Europe, but were visibly and statistically more distinct $(P=0.05)$ by latitude $45^{\circ} \mathrm{N}$, when $\mathrm{LC}$ harriers passed the Central Pyrenees along the Atlantic side, while SW harriers crossed more on the Mediterranean/eastern side (Fig.1a, SI Fig. S1A, Table S1). SW harriers thereafter followed the Mediterranean coast until they initiated seacrossings as far north as Valencia, and even Catalonia (NE Spain). LC harriers, by contrast, arrived almost directly at the Strait of Gibraltar by continuing on a south-westward course after crossing the Pyrenees (Fig 1a). The longitudinal separation between migration corridors was greatest at the Mediterranean $\left(\sim 35^{\circ} \mathrm{N}\right.$, Table S1). In Africa migration corridors increasingly overlapped again, especially as the harriers approached their respective non-breeding sites (Fig. 1a, SI Table S1). This statistical overlap was strongly influenced by the LC harrier with the easternmost first non-breeding site in the Inner Niger Delta (BE_M4), because it already started heading eastward at the Mediterranean. Analogously, the SW harrier with the westernmost non-breeding site (SW_F3) moved into the migration corridor of LC harriers already in North Africa (Fig. 1; SI Figs. S1, S2).

All but two harriers used at least two distinct nonbreeding sites (SI Fig. S2, Table S2). Inspection of satellite imagery in Google Earth suggests that some LC harriers used farmland habitats in the Sahel or near the coast throughout the entire non-breeding season (Table S2). However, most harriers, including all SW harriers, clearly moved to wetland habitats in floodplains and coastal deltas by early December (SI Fig. S2, Table S2). The direction of intra-African movements was highly variable, resulting in strong overlap of the non-breeding ranges of both groups, with notable clusters of SW and LC non-breeding sites in the Mauritanian-Senegalese border region, along the Senegalese and Guinean coast, and the Inner Niger Delta (SI Fig. S2).

\section{Spring migration corridors}

As expected, all but two harriers converged near the Atlantic coast of West Africa to cross the Sahara in spring 
Fig. 1 a Autumn migration routes and (b) spring migration routes of LC (blue) and SW (red) Marsh Harriers in the West African-Eurasian flyway, (c) with corresponding timing of latitudinal movements. Stopovers are highlighted by dots, whereby size of coloured dots on maps indicates stop-over duration (in days) (color figure online)
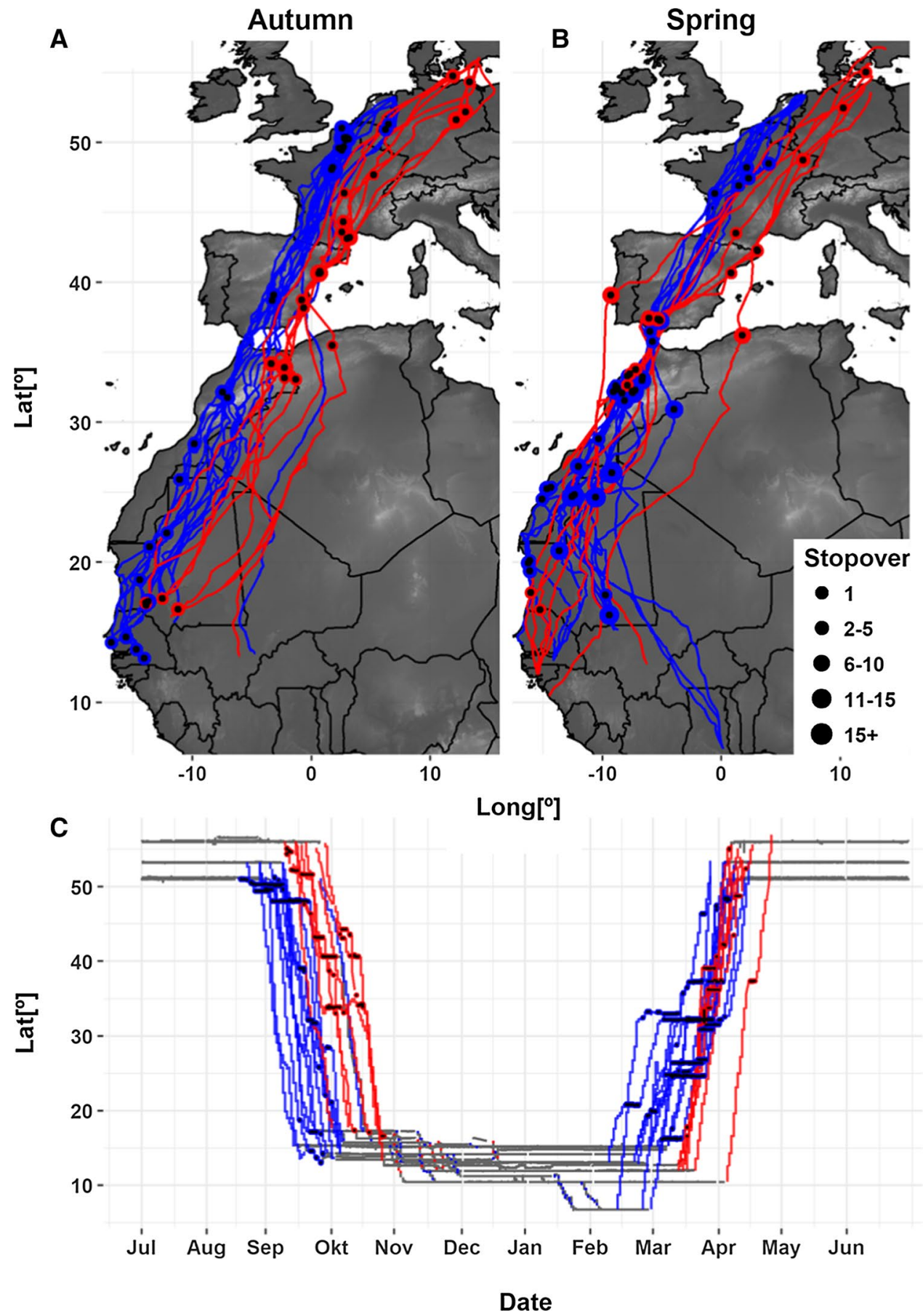

(Fig. 1, Table S1). The northwest African coast then seemed to act as a leading line towards the Strait of Gibral$\operatorname{tar}$ (SI Fig S1B). The only two individuals that did not make a western detour across the Sahara were those that wintered in the Inner Niger Delta. They directly crossed the Sahara and the Mediterranean along a more eastern route: BE_M4 crossed from Tunisia to Italy and died in the Alps (not shown on maps) and SW_M1 crossed directly from Algeria to NE Spain (Fig. 1, SI Figs. S1-2).
After reaching mainland Europe the harriers diverged into distinct migration corridors (SI Table S1). LC harriers thereby consistently crossed the Pyrenees on the western side, as they do in autumn (Fig. 1). Two SW harriers also returned via the western Pyrenees on at least one spring migration each (SW_F1, SW_F3; Fig. 1, SI Fig. S1), but we do not know if this was the habitual route of SW_F3, while the spring route choice of SW_F1 was unusually flexible compared to other SW harriers (SI Fig. S1, Vardanis 
et al. 2011). In general, the seasonal migration corridors of both groups matched the loxodromes between their breeding and wintering areas (Vansteelant et al. 2017b), except when crossing the desert in spring.

\section{Seasonal timing}

In line with our expectations, Marsh Harriers breeding in the Low Countries departed on autumn migration approximately 2 weeks before conspecifics breeding in Sweden (Fig. 1c, SI Table S3). The entire autumn migration took 23-48 days, and normally harriers spent less than 7 days stoppingover (Table 1, SI Table S3). LC harriers made the longest autumn stop-overs in NW Europe shortly upon departing from their breeding area, and occasional short stop-overs while crossing the Sahara. SW harriers stopped-over more often in southern Europe and North Africa, apparently just prior to or after their relatively longer sea-crossings (Fig. 1a, SI Fig. S1A, Table S4). The duration of autumn migration was similar between both groups so that LC harriers arrived approx. 16 days earlier to West Africa than SW harriers (Fig. 1c, SI Fig. S1c, Table S3).

LC harriers initiated their spring migration on average 3 weeks before SW harriers (Fig. 1c, SI Table S3) after which they made long stop-overs in the Sahara and North Africa (Fig. 1a, c; Table S4). By contrast, SW harriers rarely
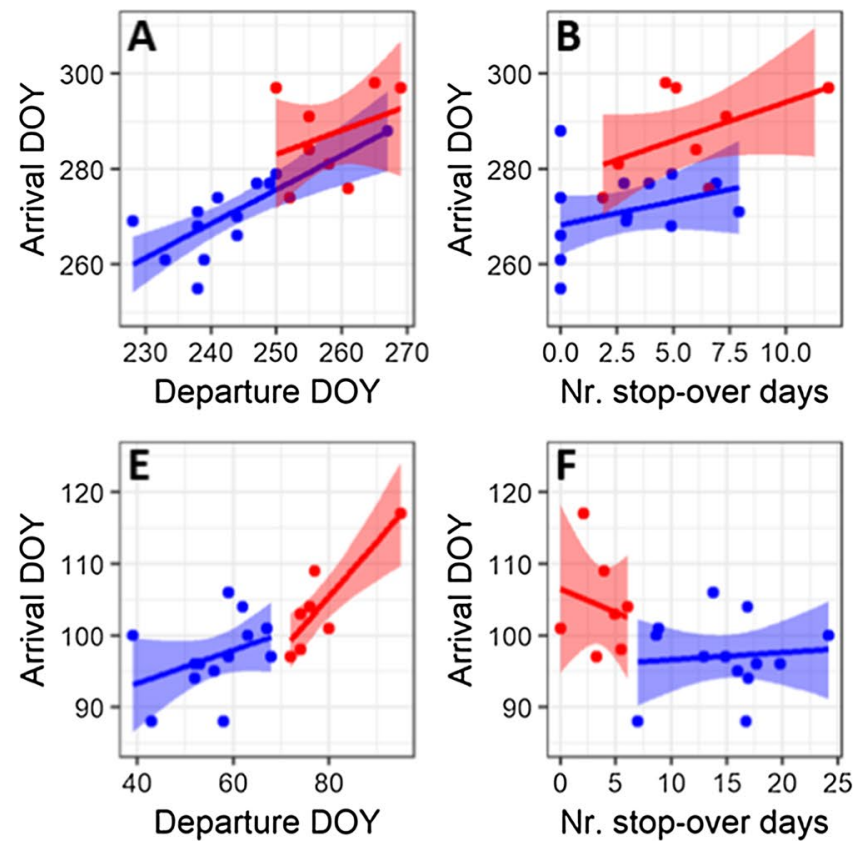

Fig. 2 Correlations between timing variables of adults breeding in the Low Countries (blue) and Southern Sweden (red) during autumn (top) and spring (bottom) migration. Each dot represents one migratory journey, including repeated journeys by individuals with longterm tracking data. Arrival date strongly correlates with departure date across and within populations in both seasons (a, e). In autumn stopped-over in spring and eventually caught up with LC harriers in North Africa (Fig. 1c). Consequently, there was no significant difference in arrival timing between LC and SW harriers (Fig. 1c, SI Table S3). Furthermore, the variability of migration timing between and within LC harriers decreased as birds reached mainland Europe. This can be seen from the convergence of tracks for BE_M2, NL_M1, NL_M2 near $30^{\circ} \mathrm{N}-35^{\circ} \mathrm{N}$ (Fig. 1c, SI Fig. S1C). Due to their long stop-overs, LC harriers often spent more time on spring than autumn migration.

\section{Correlates of stop-over behaviour}

Arrival dates were not directly correlated with the number of stop-over days (Fig. 2b, f), but were strongly correlated with departure dates in autumn, and to a lesser extent in spring (Fig. 2a, e; SI Table S5). As expected, the total duration of seasonal journeys was highly correlated with the number of stop-over days (Fig. 2c, g), but in spring the number of stop-over days was highly and inversely correlated with departure timing from West Africa (Fig. 2d, $\mathrm{H}$; Table S6). Spring migration schedules thus varied on a spectrum from early departures coupled with long stopovers to late departures coupled with few stop-overs, with most LC harriers in the former and most SW harriers in the latter category (Fig. $2 \mathrm{~g}, \mathrm{~h}$ ). That is why SW harriers
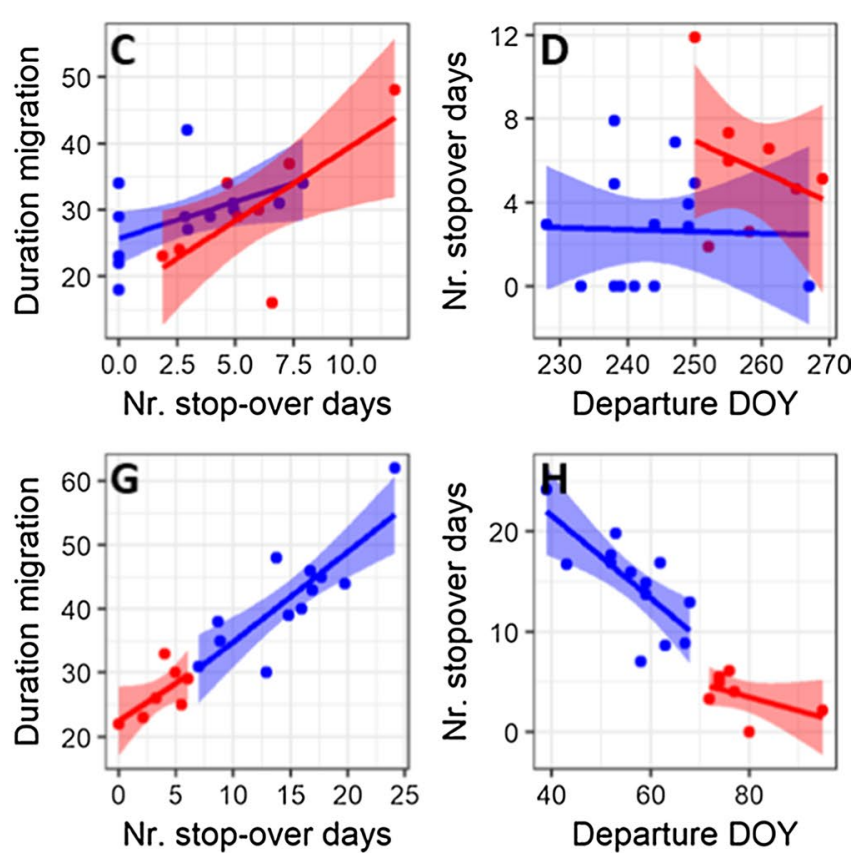

but not spring, arrival date is positively correlated with the number of stop-over days within each population $(\mathbf{b}, \mathbf{f})$. There is a very strong relationship between the duration of migration and the number of stop-over days across populations in both seasons $(\mathbf{c}, \mathbf{g})$. In spring, the number of stop-over days is strongly correlated with departure dates across populations $(\mathbf{d}, \mathbf{h})$ (color figure online) 
caught up with LC harriers, and why spring arrival timing was similar between groups and only weakly correlated to departure timing (Fig. 2a, e). A model accounting for additive effects of departure date and stop-over days did explain most variations in spring arrivals (SI Table S5).

Interestingly, the trade-off between departure timing and stop-over days persists at individual level too. For example, NL_M2 departed from Ghana anywhere between mid-February and mid-March and adjusted stop-over duration in West or North Africa accordingly, ultimately continuing his migration to Europe around mid-March, when most other harriers pass through North Africa (Table 1, SI Fig. S1c).

In Europe stop-over days were mostly characterized by stronger headwinds than travel days in both seasons (Fig. 3, SI Table S7, Table S8), indicating that wind conditions mediated stop-over decisions there. However, SW harriers frequently made stop-overs just before or after barrier-crossings that were not correlated with headwinds (Fig. 3, Table S7). We do not know if these birds may have stopped due to other adverse weather conditions (e.g. rainfall), but given the locations where they stopped it seems likely they prepared for (or recovered from) long sea-crossings in these places. In Africa, stop-overs were conducted independently from wind conditions in both seasons (Fig. 3, Table S7).

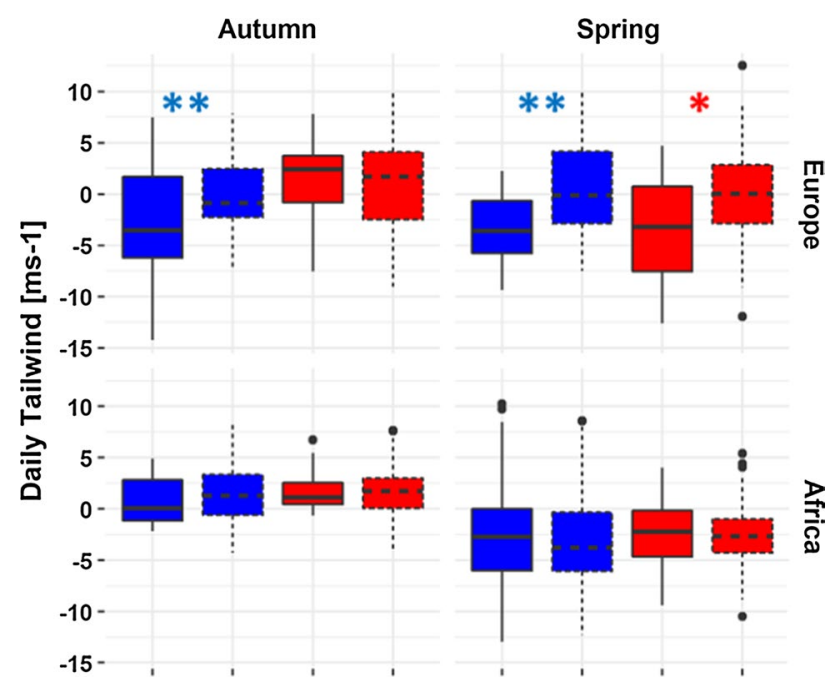

Fig. 3 Comparing daily tailwind speed on rest days (solid boxplot) vs. travel days (dashed boxplots) of adult Marsh Harriers from the Low Countries (blue) and Sweden (red). To consider wind selectivity within a seasonal and regional context, we split analyses between autumn (left) and spring migration (right) and between Europe (top) and Africa (bottom), respectively. Each boxplot shows the median daily tailwind strength (midline), the inter-quartile range (IQR, hinges), 1.5xIQR (whiskers) and outliers (points). Asterisks indicate significance of differences in daily tailwind speed between rest and travel days within each group: $P<0.1(*), P<0.01(* *)$ (color figure online)

\section{Discussion}

While the Marsh Harrier is a broad-front migrant (Spaar and Bruderer 1997; Spaar 1997; Agostini and Panuccio 2010) individuals breeding at different longitudes are expected to migrate along distinct migration corridors (cf. Trierweiler et al. 2014). However, while Marsh Harriers from the Low Countries (LC) and southern Sweden (SW) rely on a largely overlapping non-breeding range, and while previously satellite-tracked SW harriers frequently drifted with sidewinds (Klaassen et al. 2011), we expected to find considerable overlap in the migration corridors of LC and SW harriers during both seasons, and especially in Africa. Instead, LC and SW harriers maintained distinct corridors throughout almost their entire autumn migration. Strong overlap of migration corridors mainly occurred during the riskiest stage of the migration cycle, namely the spring desert-crossing until the Strait of Gibraltar (Strandberg et al. 2010; Klaassen et al. 2014). Hereinafter we will discuss the implications of these results for understanding this species' migratory orientation.

As for migration timing, it is often assumed that migratory departure timing is an individually repeatable trait under strong endogenous control (Vardanis et al. 2016), that birds ought to complete spring migrations faster than autumn trips (Nilsson et al. 2013), and that individuals breeding at lower latitudes ought to migrate earlier (Conklin et al. 2010; Briedis et al. 2016). However, the way in which LC harriers timed their spring migrations, and the way in which their behaviour compared to SW harriers, is not consistent with these conventional optimal migration paradigms.

We acknowledge that our restricted sample size warrants cautious interpretations of these results. However, the migration patterns of GPS-tracked SW harriers (the smallest group in our study) are highly consistent with those previously reported for a larger sample of satellitetracked individuals (Strandberg et al. 2008; Klaassen et al. 2010; Vardanis et al. 2011). As such we are reasonably confident that our results reflect robust population-specific migration patterns, and merit a detailed discussion.

\section{Seasonal migration corridors}

Our results reveal that LC harriers consistently rely on stop-over opportunities in NW Morocco, a region that is commonly used by Montagu's Harriers on spring migration as well (Trierweiler et al. 2014). However, even though several other loop migrations by African-Eurasian migrants are thought to be configured along foraging hotspots (Shamoun-Baranes et al. 2003; Tøttrup et al. 2012; 
Willemoes et al. 2014; Evens et al. 2017), Marsh Harriers from both our study populations used the western detour out of Africa, regardless of whether they engaged in long spring stop-overs. Moreover, the Sahara may not be entirely devoid of foraging opportunities for harriers (cf. Montagu's Harriers; Klaassen et al. 2017), while the western detour is also intensively used by species that do not forage on migration (Vansteelant et al. 2017b). This suggests that Marsh Harriers do not detour westward out of Africa to reach the stop-over hot-spots in NW Africa (they could also travel there along a more inland route), but that they do so largely in response to prevailing winds over the Sahara (Klaassen et al. 2010, 2011; Vansteelant et al. 2017b). More specifically, the orientation behaviour of SW harriers indicates the aggregation of Marsh Harriers in the western spring corridor is largely due to wind drift (cf. Klaassen et al. 2010, 2011). This differs from the strategy of Honey Buzzards Pernis apivorus that already initiate the western detour by travelling upwind over tropical Africa, and then exploit windows of opportunity with supportive winds to cross the desert (Vansteelant et al. 2015, 2017b). Indeed, Marsh Harriers did not benefit from tailwinds along the western detour (Fig. 3) as much as Honey Buzzards do. That said, fighting the prevailing north-easterlies over the desert would arguably be an even more risky strategy, not to mention the risk of getting stuck in, or being blown off course by, intense spring dust-storms (Strandberg et al. 2010; Vansteelant et al. 2015, 2017b; Agostini et al. 2019).

The longitudinal separation of migration corridors between LC and SW harriers is consistent with what has been found in other broad-front migrants like Montagu's Harriers (Trierweiler et al. 2014). However, LC and SW harriers tended along distinct migration corridors for longer than we expected while moving to their common nonbreeding range. These routes closely match the loxodromic route from their respective breeding areas, which is very likely due the prevalence of tailwinds in autumn, and may be further exacerbated by the use of distinct intermediate goals along the way (Strandberg et al. 2008; Klaassen et al. 2010). Indeed, there was a clear tendency for LC harriers to cross the Pyrenees and the Mediterranean further west than SW harriers. The non-significant overlap of LC and SW migration corridors over the Sahara was mainly caused by individuals that wintered at the western or eastern limits of the non-breeding range. As such we suspect we would find stronger overlap of autumn migration corridors when tracking a larger number of individuals, especially over Africa when harriers start navigating towards their individual nonbreeding sites.

The separation between migration corridors over Europe was less pronounced during spring than during autumn (Fig. 1), especially due to one SW harrier with exceptionally flexible spring routes (SW_F1). If we also consider the old satellite-tracking data for SW harriers (Strandberg et al. 2008; Klaassen et al. 2010, 2011), however, it does seem Marsh Harriers minimize the remaining migration distance to their respective breeding areas after reaching mainland Europe (Fig. 1b). Indeed, the trans-European migration corridors of LC and SW harriers, respectively, crossing the Pyrenees on the western and eastern side, closely match the loxodromic routes between their breeding and non-breeding ranges. Rather than being inherited, however, these population-specific migration corridors probably emerge as immature harriers learn to minimize travel distance and improve migratory performance with experience (Sergio et al. 2014; Agostini et al. 2019). In fact, similar to our adult Marsh Harriers, experienced Honey Buzzards breeding in the Low Countries and Sweden converge in narrow migration corridors on opposing sides of the Pyrenees too (Hake et al. 2003; Vansteelant et al. 2015, 2017b). And while it is well established that Honey Buzzards do not inherit these routes genetically or culturally on their first migrations (Schmid 2000; Hake et al. 2003; Thorup et al. 2003; Vansteelant et al. 2017a), we suspect the same is true for Marsh Harriers.

\section{Migration timing}

Another important finding in our study is that migration timing of LC and SW harriers differed in a much more complex manner than one would expect based on the latitudinal difference between their breeding areas (Conklin et al. 2010; Briedis et al. 2016). We revealed a broad spectrum of spring migration schedules, ranging from early-departing birds that make long stop-overs to late-departing birds with few or no stop-overs (cf. the more extreme case of Black-tailed Godwit Limosa limosa, Verhoeven et al. 2019), whereby all LC harriers used the former strategy at least once, and only one SW harrier has ever been recorded to use this strategy (Strandberg et al. 2008). Even more intriguing is that the variability and flexibility of spring migration timing sharply decreased as birds progressed northward (cf. Verhoeven et al. 2019), with both groups ultimately completing migration around the same time. That $\mathrm{LC}$ harriers made longer stop-overs than SW harriers is inconsistent with the conventional expectation for stop-over time to increase with migration distance (Alves et al. 2012; Monti et al. 2018).

Given that male birds tend to migrate earlier than females in many species (Mueller et al. 2000; Both et al. 2016), our results might be biased by the higher proportion of males in our sample of LC harriers (100\%) vs. SW harriers (50\%). However, there is no evidence that female SW harriers start or finish their migrations later than males (Strandberg et al. 2008), and early departures by male LC harriers did not result in particularly early arrivals. Moreover, the long stopovers by LC harriers resulted in a much slower spring than 
autumn migration (cf. Carneiro et al. 2018), while optimal migration theory usually predicts the opposite pattern (Nilsson et al. 2013; Schmaljohann 2018). These results suggest that selection for early arrival of males and at lower latitudes is buffered by other factors in our study species. In this regard, it is worth noting that Marsh Harrier is a generalist predator (Cardador et al. 2012), with a differential but broad diet in both sexes, and therefore unlikely to optimize its spring arrival and laying dates to the phenology of any one single prey species. Moreover, they increasingly breed in agricultural landscapes (incl. all our study birds), where breeding success is heavily affected by human disturbance and predation (Anselin and Degraeve 2018).

Long spring stop-overs in North Africa were not necessitated by wind conditions (Shamoun-Baranes et al. 2010; Carneiro et al. 2018). Instead, we believe that early departures towards North African stop-over sites are a strategic response to deteriorating foraging conditions at nonbreeding sites that progressively dry out towards the end of the non-breeding season (Moreau 1961, Schlaich et al. 2016). Interestingly, it has been shown that, like our study species, individual White Storks Ciconia ciconia also vary on a spectrum from early and slow to late and fast spring migrants, and that early-departing individuals were those that faced higher foraging costs in more arid non-breeding areas (Rotics et al. 2018). It is unclear, however, why LC and SW harriers would experience differential foraging costs at their respective non-breeding sites. Again, one could argue the uneven sampling of sexes between SW and LC harriers is relevant here, because females account for roughly $60 \%$ of Marsh Harrier observations in West African wetlands, while the vast majority of Marsh Harriers seen foraging in arid parts of the Sahel are males (Bijlsma 2009, pers. obs. B. Koks). And indeed, both female SW harriers in our study spent most of the non-breeding season in coastal wetlands, where prey availability probably does not deteriorate as much as in savannah habitats. However, also both the late-departing male SW harriers moved into or near wetland habitats by the end of the non-breeding season, as did half of the early-departing male LC harriers. Moreover, it could be that some males which we determined to stay in wetlands actually used more arid habitat patches at a fine spatial scale (pers. obs. B. Koks). Therefore, our small sample size does not allow to formally test whether non-breeding habitat selection differs between sexes and populations, and how this may affect spring migration timing. Regardless of these limitations, however, it is clear that male LC harriers are much more likely to depart early in spring than male SW harriers (only one early-departing male in Strandberg et al. 2008, Vardanis et al. 2011). As such, the uneven sampling of sexes alone does not seem to be a satisfactory explanation for the differences we observed in spring departure timing of LC and SW harriers. Instead, we propose that individual harriers may develop different non-breeding habits in early life, possibly depending on their population-specific autumn arrival to West Africa. More specifically, LC harriers might be more tempted to linger in savannah habitats that are still green and productive at the time they arrive to the Sahel, whereas SW harriers may proceed to look for natural floodplains, rice fields or other wetlands shortly after their late arrival. This, of course, is entirely speculative, and future studies should strive to track a large number of Marsh Harriers from fledging to adulthood in order to determine how individual, sex- and population-specific migration patterns develop in this species.

\section{Conclusions}

Marsh Harriers from nearby breeding areas in the Low Countries and southern Sweden use distinct autumn migration corridors, but use the same western corridor to cross the Sahara in spring. We speculate that population-specific migration corridors emerge as harriers learn to minimize migration distance over Europe. Regarding timing we found that SW harriers depart and arrive two weeks later than LC harriers in autumn, but not due to a consistent shift of annual cycles with breeding latitude. Instead, spring departure timing was highly variable and flexible in LC harriers, and variability in timing decreased as birds progressed northward and both groups ultimately arrived to their breeding areas around the same time. We suspect that harriers depart from West Africa at earlier and more variable dates when they face poorer and more variable foraging conditions at their non-breeding sites. Longitudinal tracking studies are needed to verify whether and how harriers from nearby breeding areas might end up using non-breeding sites of different quality. Even though the causes and consequences of differential spring migration strategies remain unclear, the existence of such large behavioural differences between nearby breeding populations using the same flyway strongly cautions against the overgeneralization of migration patterns observed in single-population tracking studies.

Acknowledgements Tracking of Marsh Harriers in the Netherlands was approved by the local ethical committee of the University of Groningen, The Netherlands (permits 5869B and 6429B). In Sweden the tracking was approved by the Ethical Committees in Uppsala (C92/6) and Malmö/Lund (204-06). Permission to capture the birds was obtained from the Swedish Environmental Protection Agency (412-429-05 Nf). We are grateful to local farmers who gave permission to study Marsh Harriers on their properties. The Belgian team is grateful to the Janssens family for hosting an UvA-BiTS base station and to Roger Janssens and Hilbran Verstraete for managing logger settings and field work assistance. The Dutch team is grateful to Staatsbosbeheer for allowing to study Marsh Harriers breeding on their terrain, to the municipality of Delfzijl for providing access to a secure site for the main antenna, to Yde de Boer and family allowed us to install an UvABiTS base station at their home, to Almut Schlaich for managing logger 
settings and assistance during field work, as well as to Tonio Schaub for providing valuable help in the field. UvA-BiTS studies are facilitated by infrastructures for e-Ecology, developed with support of NLeSC and LifeWatch and carried out on the Dutch national e-infrastructure with the support of SURF Cooperative. In Sweden, the Marsh Harrier research was coordinated by Thomas Alerstam and we are grateful to all volunteers who participated in the field work there. We thank Nicolantonio Agostini, Rob Bijlsma and an anonymous reviewer for useful feedback on earlier versions of this manuscript.

Funding The Belgian Marsh Harrier project makes use of data and infrastructure provided by INBO and VLIZ and funded by Research Foundation-Flanders (FWO) as part of the Belgian contribution to LifeWatch. The Belgian GPS-trackers are part of the Flemish contribution to LifeWatch ERIC and were funded by the FWO. The Dutch project was largely self-funded by the Montagu's Harrier Foundation with additional financial support from the province of Flevoland to purchase a tracking system. The Swedish study was funded by personal grants from the Swedish Research Council to Thomas Alerstam and to R.K. and a grant from the Niels Stensen Foundation to R.K.

Data availability All tracking data from Flanders and the Netherlands is published through the Movebank Data Repository (Anselin et al. 2019; Koks et al. 2019). The Swedish data can be found under Movebank ID $49,909,355$. Resampled data, R code and detailed instructions on how to reproduce our analyses and figures are provided via GitHub (https ://github.com/inbo/wmh-analysis). For the sake of transparency, the scripts we used to resample and filter the raw Dutch and Belgian data are also provided. Spatial layers needed to reproduce our maps are freely available online and downloaded automatically when running the $\mathrm{R}$ code.

Open Access This article is licensed under a Creative Commons Attribution 4.0 International License, which permits use, sharing, adaptation, distribution and reproduction in any medium or format, as long as you give appropriate credit to the original author(s) and the source, provide a link to the Creative Commons licence, and indicate if changes were made. The images or other third party material in this article are included in the article's Creative Commons licence, unless indicated otherwise in a credit line to the material. If material is not included in the article's Creative Commons licence and your intended use is not permitted by statutory regulation or exceeds the permitted use, you will need to obtain permission directly from the copyright holder. To view a copy of this licence, visit http://creativecommons.org/licenses/by/4.0/.

\section{References}

Anselin A, Desmet P, Milotic T, Janssens K, T'Jollyn F, De Bruyn L, Bouten W (2019) MH_WATERLAND_Western marsh harriers (Circus aeruginosus, Accipitridae) breeding near the Belgium-Netherlands border. Dataset. https://doi.org/10.5281/ zenodo. 3532940

Agostini N, Panuccio M (2010) Western Marsh Harrier (Circus aeruginosus) migration through the Mediterranean Sea: a review. J Raptor Res 44:136-142

Agostini N, Prommer M, Váczi M, Panuccio M (2019) Repeated large scale loop migrations of an adult European Honey Buzzard. Avocetta 43:13-21

Alerstam T (2001) Detours in bird migration. J Theor Biol 209:319-331

Alves JA, Gunnarsson TG, Potts PM, Gélinaud G, Sutherland WJ, Gill JA (2012) Overtaking on migration: Does longer distance migration always incur a penalty? Oikos 121:464-470
Anselin A, Degraeve K (2018) Van rietmoeras naar graangewas: nestbescherming bij de bruine kiekendief in vlaanderen. natuur.oriolus-Themanr. Akkervogels 84:50-57

Bates D, Maechler M, Bolker B, Walker S (2015) Fitting Linear MixedEffects Models Using lme4. J Stat Softw 67:1-48

BeBirds (2019) BeBirds: ringing recoveries. https://odnature.naturalsci ences.be/bebirds/en/ring-recoveries Accessed 21 Dec 2019

Bijlsma RG (2009) Eurasian Marsh Harrier, Circus aeruginosus. In: Zwarts L, et al. (eds) Living on the edge. KNNV Publishing, Wetlands and birds in a changing Sahel, pp 304-311

Both C, Bijlsma RG, Ouwehand J (2016) Repeatability in spring arrival dates in pied flycatchers varies among years and sexes. Ardea 104:3-21

Bouten W, Baaij EW, Shamoun-Baranes J, Camphuysen KCJ (2013) A flexible GPS tracking system for studying bird behaviour at multiple scales. J Ornithol 154:571-580

Briedis M, Hahn S, Gustafsson L, Henshaw I, Träff J, Král M, Adamík P (2016) Breeding latitude leads to different temporal but not spatial organization of the annual cycle in a longdistance migrant. J Avian Biol 47:743-748

Cardador L, Planas E, Varea A, Mañosa S (2012) Feeding behaviour and diet composition of Marsh Harriers Circus aeruginosus in agricultural landscapes. Bird Study 59:228-235

Carneiro C, Gunnarsson TG, Alves JA (2018) Faster migration in autumn than in spring: seasonal migration patterns and nonbreeding distribution of Icelandic Whimbrels Numenius phaeopus islandicus. J Avian Biol. https://doi.org/10.1111/jav.01938

Chapman JW, Klaassen RHG, Drake VA, Fossette S, Hays GC, Metcalfe JD, Reynolds AM, Reynolds DR, Alerstam T (2011) Animal orientation strategies for movement in flows. Curr Biol 21:R861-R870

Conklin JR, Battley PF, Potter M, Fox JW (2010) Breeding latitude drives individual schedules in a trans-hemispheric migrant bird. Nat Commun 1:67

De la Cruz A, Onrubia A, Pérez B, Torralvo C, Arroyo GM, Elorriaga J, Ramírez J, González M, Benjumea R (2011a) Seguimiento de la migración de las aves en el estrecho de Gibraltar: resultados del Programa Migres 2009. Migres 2:65-78

De la Cruz A, Arroyo GM, Onrubia A, Barrios L, Muñoz AR (2011b) Migración primaveral de aves planeadoras en el Estrecho de Gibraltar. Diseño de un programa de seguimiento a largo plazo. Migres 2:79-88

Evens R, Conway GJ, Henderson IG, Cresswell B, Jiguet F, Moussy C, Sénécal D, Witters N, Beenaerts N, Artois T (2017) Migratory pathways, stopover zones and wintering destinations of Western European Nightjars Caprimulgus europaeus. Ibis (Lond 1859) 159: 680-686

Finch T, Butler SJ, Franco AMA, Cresswell W (2017) Low migratory connectivity is common in long-distance migrant birds. J Anim Ecol 86:662-673

Fransson T, Pettersson J (2001) Swedish Bird Ringing Atlas (Volume 1: Divers-Raptors). Swedish Museum of Natural History, Stockholm

Hake M, Kjellen N, Alerstam T (2003) Age-dependent migration strategy in honey buzzards Pernis apivorus tracked by satellite. Oikos 103:385-396

Hasselquist D, Montràs-Janer T, Tarka M, Hansson B (2017) Individual consistency of long-distance migration in a songbird: significant repeatability of autumn route, stopovers and wintering sites but not in timing of migration. J Avian Biol 48:91-102

Jiguet F, Robert A, Lorrillière R, Hobson KA, Kardynal KJ, Arlettaz R, Bairlein F, Belik V, Bernardy P, Copete JL, Czajkowski MA, Dale S, Dombrovski V, Ducros D, Efrat R, Elts J, Ferrand Y, Marja R, Minkevicius S, Olsson P, Pérez M, Piha M, Raković M, Schmaljohann H, Seimola T, Selstam G, Siblet JP, Skierczyǹski M, Sokolov A, Sondell J, Moussy C (2019) 
Unravelling migration connectivity reveals unsustainable hunting of the declining ortolan bunting. Sci Adv 5: eaau2642.

Kemp MU, van Loon E, Shamoun-Baranes J, Bouten W (2012) RNCEP: Global weather and climate data at your fingertips. Methods Ecol Evol 3:65-70

Klaassen RHG, Strandberg R, Hake M, Alerstam T (2008) Flexibility in daily travel routines causes regional variation in bird migration speed. Behav Ecol Sociobiol 62:1427-1432

Klaassen RHG, Strandberg R, Hake M, Olofsson P, Tøttrup AP, Alerstam T (2010) Loop migration in adult Marsh Harriers Circus aeruginosus, as revealed by satellite telemetry. J Avian Biol 41:200-207

Klaassen RHG, Hake M, Strandberg R, Alerstam T (2011) Geographical and temporal flexibility in the response to crosswinds by migrating raptors. Proc R Soc B-Biological Sci 278:1339-1346

Klaassen RHG, Hake M, Strandberg R, Koks BJ, Trierweiler C, Exo KM, Bairlein F, Alerstam T (2014) When and where does mortality occur in migratory birds? Direct evidence from long-term satellite tracking of raptors. J Anim Ecol 83:176-184

Klaassen RHG, Schlaich AE, Bouten W, Koks BJ (2017) Migrating Montagu's harriers frequently interrupt daily flights in both Europe and Africa. J Avian Biol 48:180-190

Koks BJ, Schlaich AE, Schaub T, Klaassen R, Anselin A, Desmet P, Milotic T, Janssens K, Bouten W (2019) H_GRONINGENWestern marsh harriers (Circus aeruginosus, Accipitridae) breeding in Groningen (the Netherlands). Dataset. Doi: 10.5281/ zenodo. 3552507

Leshem Y, Yom-Tov Y (1996) The use of thermals by soaring migrants. Ibis (Lond 1859). 138: 667-674

Mellone U, Klaassen RHG, García-Ripollés C, Limiñana R, LópezLópez P, Pavón D, Strandberg R, Urios V, Vardakis M, Alerstam $\mathrm{T}$ (2012) Interspecific comparison of the performance of soaring migrants in relation to morphology, meteorological conditions and migration strategies. PLoS ONE 7:e39833

Meyer SK, Spaar R, Bruderer B (2000) To cross the sea or to follow the coast? Flight directions and behaviour of migrating raptors approaching the Mediterranean Sea in autumn. Behaviour 137:379-399

Monti F, Grémillet D, Sforzi A, Dominici JM, Bagur RT, Navarro AM, Fusani L, Klaassen RHG, Alerstam T, Duriez O (2018) Migration distance affects stopover use but not travel speed: contrasting patterns between long- and short-distance migrating ospreys. J Avian Biol 49:e01839

Mueller HC, Mueller NS, Berger DD, Allez G, Robichaud W, Kaspar JL (2000) Age and sex differences in the timing of fall migration of hawks and falcons. Wilson Bull 112:214-224

Nilsson C, Klaassen RHG, Alerstam T (2013) Differences in speed and duration of bird migration between spring and autumn. Am Nat 181:837-845

Ouwehand J, Ahola MP, Ausems ANMA, Bridge ES, Burgess M, Hahn S, Hewson CM, Klaassen RHG, Laaksonen T, Lampe HM, Velmala W, Both C (2016) Light-level geolocators reveal migratory connectivity in European populations of pied flycatchers Ficedula hypoleuca. J Avian Biol 47:69-83

Panuccio M, Mellone U, Muner L (2013) Differential wintering area selection in eurasian marsh harrier (Circus aeruginosus): a ringing recoveries analysis. Bird Study 60:52-59

R Core Development Team 2017. R: a language and environment for statistical computing.

Rotics S, Kaatz M, Turjeman S, Zurell D, Wikelski M, Sapir N, Eggers U, Fiedler W, Jeltsch F, Nathan R (2018) Early arrival at breeding grounds: Causes, costs and a trade-off with overwintering latitude. J Anim Ecol 87:1627-1638

Schmaljohann H (2018) Proximate mechanisms affecting seasonal differences in migration speed of avian species. Sci Rep 8:4106
Schmid H (2000) Separate routes: autumn migration of juvenile and adult European Honey-buzzards Pernis apivorus - a synthesis. Ornithol Beob 97:191-222

Sergio F, Tanferna A, De Stephanis R, López Jiménez L, Blas J, Tavecchia G, Preatoni D, Hiraldo F (2014) Individual improvements and selective mortality shape lifelong migratory performance. Nature 515:410-413

Shamoun-Baranes J, Baharad A, Alpert P, Berthold P, Yom-Tov Y, Dvir Y, Leshem Y (2003) The effect of wind, season and latitude on the migration speed of white storks $s$, along the eastern migration route. J Avian Biol 34:97-104

Shamoun-Baranes J, Leyrer J, van Loon E, Bocher P, Robin F, Meunier F, Piersma T (2010) Stochastic atmospheric assistance and the use of emergency staging sites by migrants. Proc Biol Sci 277:1505-1511

Somveille M, Rodrigues ASL, Manica A (2015) Why do birds migrate? A macroecological perspective. Glob Ecol Biogeogr 24:664-674

Spaar R (1997) Flight strategies of migrating raptors: a comparative study of interspecific variation in flight characteristics. Ibis (Lond. 1859). 139: 523-535

Spaar R, Bruderer B (1997) Migration by flapping or soaring: flight strategies of marsh, Montagu's and pallid harriers in southern Israel. Condor 99:458-469

Strandberg R, Klaassen RHG, Hake M, Olofsson P, Thorup K, Alerstam T (2008) Complex timing of Marsh Harrier Circus aeruginosus migration due to pre- and post-migratory movements. Ardea 96:159-171

Strandberg R, Klaassen RHG, Hake M, Alerstam T (2010) How hazardous is the Sahara Desert crossing for migratory birds? Indications from satellite tracking of raptors. Biol Lett 6:297-300

Thorup K, Alerstam T, Hake M, Kjellén N (2003) Bird orientation: compensation for wind drift in migrating raptors is age dependent. Proc R Soc B Biol Sci 270:S8-S11

Thorup K, Alerstam T, Hake M, Kjellén N (2006) Travelling or stopping of migrating birds in relation to wind: an illustration for the osprey. Behav Ecol 17:497-502

Thorup K, Tøttrup AP, Willemoes M, Klaassen RHG, Strandberg R, Vega ML, Dasari HP, Araújo MB, Wikelski M, Rahbek C (2017) Resource tracking within and across continents in long-distance bird migrants. Sci Adv 3:e1601360

Tøttrup AP, Klaassen RHG, Kristensen MW, Strandberg R, Vardanis Y, Lindström Å, Rahbek C, Alerstam T, Thorup K (2012) Drought in Africa caused delayed arrival of European songbirds. Science 338:1307

Trierweiler C, Klaassen RHG, Drent RH, Exo KM, Komdeur J, Bairlein F, Koks BJ (2014) Migratory connectivity and populationspecific migration routes in a long-distance migratory bird. Proc Biol Sci 281:20132897

van Wijk RE, Schaub M, Bauer S (2017) Dependencies in the timing of activities weaken over the annual cycle in a long-distance migratory bird. Behav Ecol Sociobiol 71:73

Vansteelant WMG, Bouten W, Klaassen RHG, Koks BJ, Schlaich AE, van Diermen J, van Loon EE, Shamoun-Baranes J (2015) Regional and seasonal flight speeds of soaring migrants and the role of weather conditions at hourly and daily scales. J Avian Biol 46:25-39

Vansteelant WMG, Kekkonen J, Byholm P (2017a) Wind conditions and geography shape the first outbound migration of juvenile honey buzzards and their distribution across sub-Saharan Africa. Proc R Soc B Biol Sci 284:20170387

Vansteelant WMG, Shamoun-Baranes J, van Diermen J, van Manen W, Bouten W (2017b) Seasonal detours by soaring migrants shaped by wind regimes along the East Atlantic Flyway. J Anim Ecol 86:179-191 
Vansteelant WMG, Shamoun-Baranes J, McLaren J, van Diermen J, Bouten W (2017c) Soaring across continents: decision-making of a soaring migrant under changing atmospheric conditions along an entire flyway. J Avian Biol 48:887-896

Vardanis Y, Klaassen RHG, Strandberg R, Alerstam T (2011) Individuality in bird migration: routes and timing. Biol Lett 7:502-505

Vardanis Y, Nilsson JA, Klaassen RHG, Strandberg R, Alerstam T (2016) Consistency in long-distance bird migration: Contrasting patterns in time and space for two raptors. Anim Behav 113:177-187

Verhoeven MA, Loonstra AHJ, Senner NR, McBride AD, Both C, Piersma T (2019) Variation from an unknown source: large interindividual differences in migrating black-tailed godwits. Front Ecol Evol. https://doi.org/10.3389/fevo.2019.00031

Vidal-Mateo J, Mellone U, López-López P, la Puente JD, García-Ripollés C, Bermejo A, Urios V (2016) Wind effects on the migration routes of trans-Saharan soaring raptors: geographical, seasonal and interspecific variation. Curr Zool 62:89-97
Vogeltrektatlas (2019). Vogeltrekatlas-Bruine Kiekendief. https:// www.vogeltrekatlas.nl/soortzoek2.html?-0-Bruine\%20kiekendi ef-Totaal Accessed 21 Dec 2019

Wickham H (2009) ggplot2: elegant graphics for data analysis. Springer, Berlin

Willemoes M, Strandberg R, Klaassen RHG, Tøttrup AP, Vardanis Y, Howey PW, Thorup K, Wikelski M, Alerstam T (2014) Narrow-front loop migration in a population of the common cuckoo Cuculus canorus, as revealed by satellite telemetry. PLoS ONE 9:e83515

Publisher's Note Springer Nature remains neutral with regard to jurisdictional claims in published maps and institutional affiliations. 